\title{
A Celebração da Química, em Modo Presencial
}

Adelino Galvão

Nos passados dias 26 e 27 de novembro realizou-se o IX Encontro da Divisão de Ensino e Divulgação da Química (IXEDEDQ). Após dois ensaios de organização de eventos em regime híbrido (o Encontro Nacional em Braga e o Encontro Internacional ISySyCat2021 em Évora), este Encontro marcou o retorno às atividades inteiramente presenciais da Sociedade Portuguesa de Química. Em todos estes eventos a SPQ demonstrou que tem capacidade organizativa para, em segurança e no estrito cumprimento das orientações de segurança sanitária, regressar ao regime presencial, em que podemos discutir ciência, lançar projetos colaborativos e celebrar a Química, cara a cara e com a componente empática do contacto próximo entre seres humanos. Neste evento em concreto, destinado aos docentes do ensino básico e secundário do Grupo 510 e creditado como ação de formação pelo CCPFCP, tivemos oportunidade de ouvir e discutir ciência proferida por cinco excelentes conferencistas, além de comunicações orais das experiências pedagógicas efetuadas no terreno pelos professores. Houve ainda tempo para publicitar o lançamento de dois livros que projetam a Química para a Sociedade, fora do círculo restrito dos cientistas, realizar oficinas de formação e um espetáculo de ciência através da magia. No final destes dois dias intensivos de trabalho respirava-se a satisfação de ter voltado a conviver entre pares tendo a Química como tema que nos apaixona.

No final de 2021 a SPQ promoveu mais alguns encontros especializados, mas o nosso objetivo é que 2022 seja já um ano de aproximação à normalidade, relativamente aos eventos SPQ, independentemente das medidas de proteção individual e comunitária que tivermos de adotar para garantir a segurança de todos os participantes. Neste sentido, lanço o repto a todos os nossos associados para que participem e se envolvam nas atividades das Divisões e Grupos, quer a nível organizativo, quer participativo, para que a dinâmica da SPQ se consolide e justifique o título de membro honorário da Ordem da Instrução Pública que nos foi atribuído, em 2021, por sua Excelência o Senhor Presidente da República.

Em 2022 teremos também o desafio de organizar o $8^{\text {th }}$ EuChems Chemistry Congress, que esperamos confirme a capacidade da SPQ como organizador de grandes eventos internacionais, na promoção da

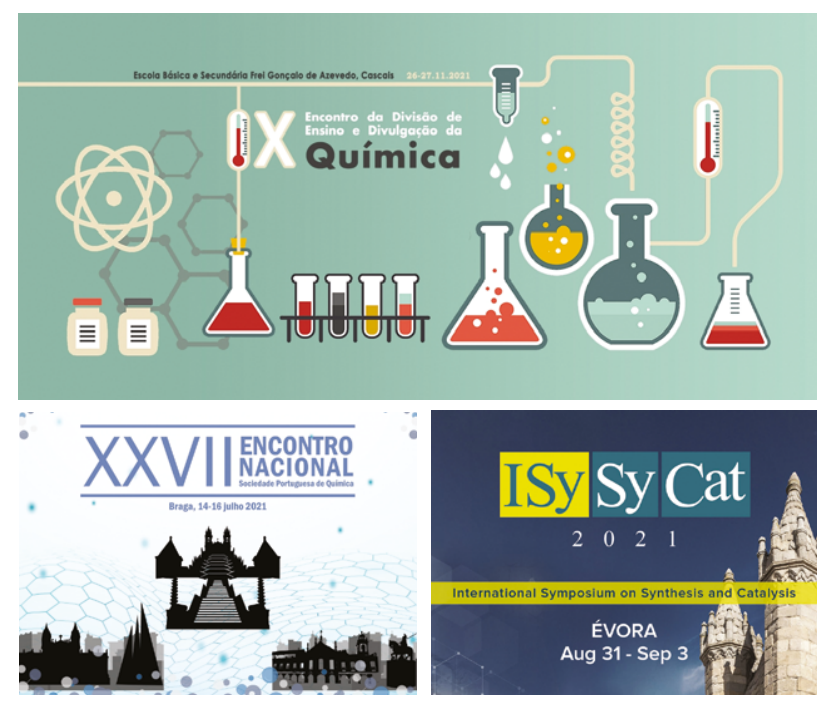

Química, enquanto ciência central, com um papel fundamental nas interfaces com a Biologia, a Medicina e as Ciências de Materiais e do Ambiente. Neste evento promoveremos a Química e o seu papel para o progresso da Humanidade e na resolução dos desafios produzidos pelas sociedades modernas.

A finalizar gostaria de, em meu nome pessoal e de toda a Direção da SPQ, desejar votos de celebrações felizes, com muita saúde e que 2022 seja um ano de concretização de projetos pessoais e profissionais em que, todos juntos, continuemos a divulgar e a promover a Química em todas as suas dimensões.

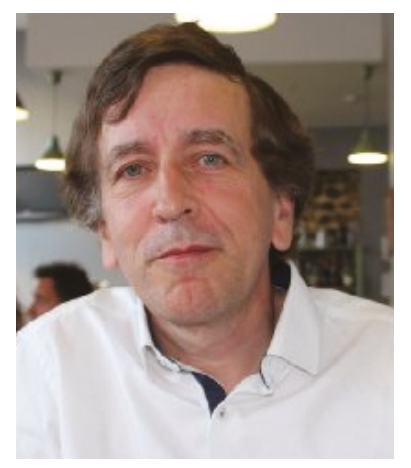

\section{Adelino Galvão}

Professor Auxiliar do Departamento de Engenharia Química, Instituto Superior Técnico, Universidade de Lisboa. Desenvolve o seu trabalho de investigação no Centro de Química Estrutural na área da Fotoquímica Computacional. É Secretário-Geral da SPQ desde 2017. adelino@tecnico.ulisboa.pt ORCID.org/0000-0002-4740-0613 
